\title{
Øgenavne og levevilkår blandt fiskerne i Slesvig
}

\section{Af Nils Vollertsen}

I Slesvig fandtes tidligere en betydelig gruppe erhvervsfiskere, som havde deres eget kvarter. Det lå på en lille ø i Slien, kaldet Holmen, og var dermed både rent fysisk og erhvervsmæssigt skilt ud af den omgivende købstad. Øen Holmen var oprindeligt skilt fra det omgivende bysamfund ved det smalle sund, Fischbrückbach, som blev fyldt op i 1935. Blandt Holmens fiskere var det almindeligt, at fiskernes sønner og døtre giftede sig ind i hinandens familier. Dette gav relativt få, men store familier, hvilket nødvendiggjorde brugen af øgenavne. Op igennem 1800-tallet og frem til 1950 havde således næsten alle fiskere et eller flere øgenavne. Også for postbudet var det en lettelse, at der på dørskiltet bag navnet var tilføjet fiskerens øgenavn. Øgenavnet kunne endda hænge så meget ved fiskeren, at det fulgte ham i døden ved at blive indmejslet i gravstenen.

I flæng skal blot nævnes: Leier, Baron, Diransch, de Aap, Mochum, Dalli, de Änt, de Woort, Bambus, Gandhi, Abs, Dickkopp, Mohrich, Ausch, Iwi, Iwan, Leus, Nacke, Leier, Buer, Jöns, Kack, Pati, Meister, Bretter, de Flottenschoster, Himmelblau, Schnieder, Setzer, Schipperduk, Scherf, Puttkammer og de dree Ministers. Dette er blot en brøkdel af de over 300 øgenavne, jeg indsamlede fra Holmen. Fælles for dem alle er dog, at de går tæt ind på fiskeren og karakteriserer denne på den ene eller anden måde. Man må altså kunne undersøge fiskerkvarterets levevilkår på baggrund af øgenavnene.

Først vil det dog være rimeligt at give et rids af fiskerlavets udvikling, som det tegner sig ud fra de skrevne kilder.

\section{Fiskerne i Slesvig 1800 - 1910}

Fiskerlejet Holmen bar helt frem til omkring 1910 præg af at være et lukket lokalsamfund, uden nærmere kontakt til det øvrige Slesvig. Holmens fiskere omfattede både vod- og netfiskere. Vodfiskerne fiskede med drivgarn (vod) over hele Slien, hvilket de mente at have ret til i kraft af Christian 1.'s Sli-brev fra 1480. Netfiskerne derimod fiskede med sættegarn (net) lige ud for Slesvig, da de hverken havde råd til at 


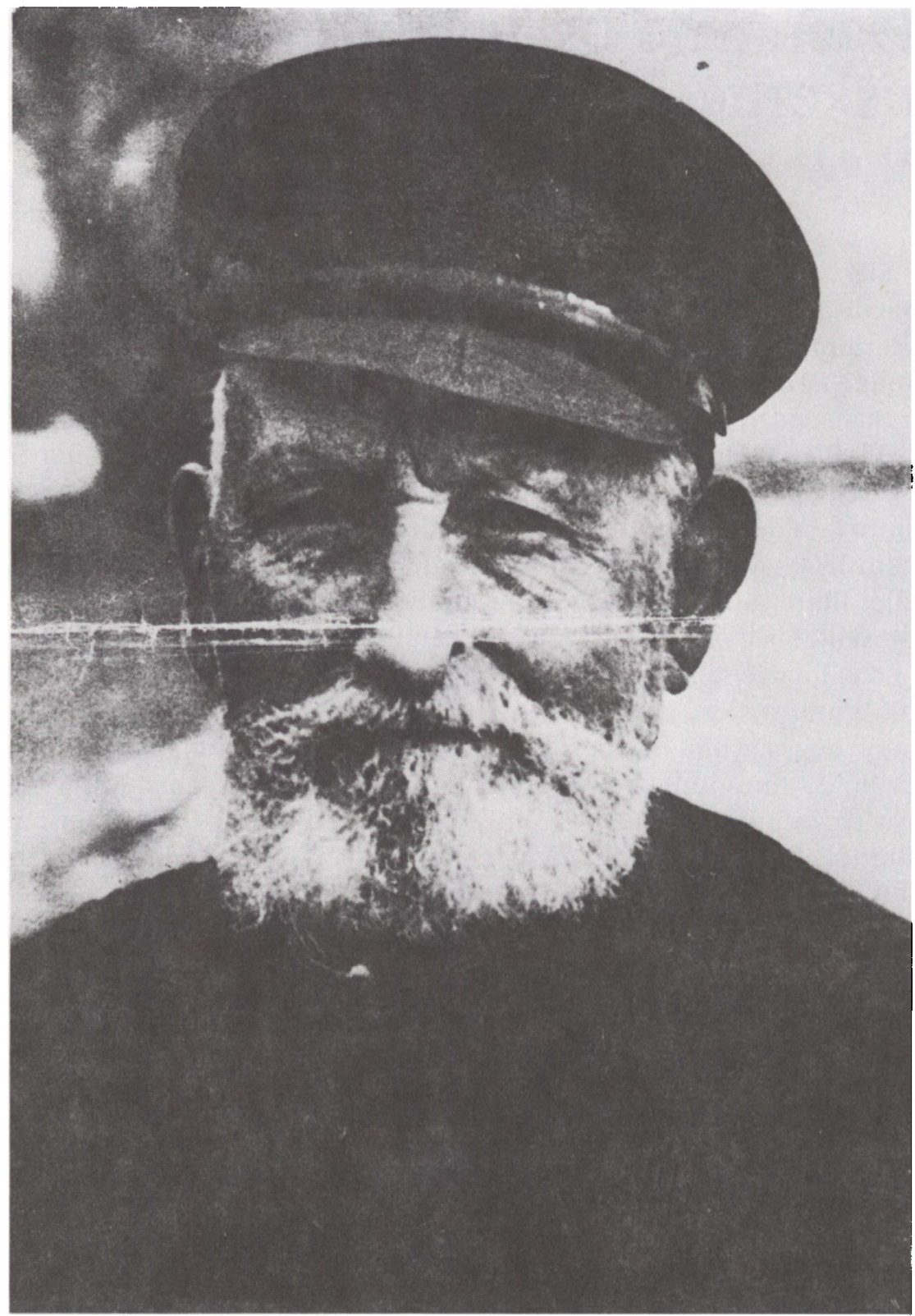

Friedrich Ross (Meister), 1880-1954, i en drrakke oldermand for fiskerlavet på Holmen. Grunden til ogenavnet Meister har ikke kunnet findes. 
betale for optagelsen i fiskerlavet eller til at købe den part garn, man skulle stille med som medlem af et vodfællesskab. I det hele taget optoges frem til 1910 kun vodfiskere i fiskerlavet, hvis medlemmer fiskede sammen i vodfællesskaber og fik del i lavets sociale sikkerhedsnet. For netfiskerne gjaldt, at de var uorganiserede og derfor overladt til sig selv.

Holmens fiskere var således ingen homogen gruppe. Det var de relativt velbeslåede vodfiskere, der tegnede fiskersamfundet lokalt, og i kraft heraf var bærerne af fiskerlejets folkekultur. Skik og brug på fiskerlejet Holmen udsprang jo netop af arbejds- og vodfællesskabet. Det gælder for arbejdssangene, øgenavnene, bryllupsceremonien samt sagnene om Sorte Gret (Margrethe 1.) og fiskerne på Holmen.

Så længe antallet af fiskere omkring 1800-50 holdt sig på godt 40-50, og der ellers var rigeligt med sild i Slien til alle, var både vod- og netfiskernes indtægter sikret. Dertil kom, at så længe fiskerlavet vár stærkt nok til at bevare, og endda i 1820erne og 30erne udbygge og fæstne, sin lokale stilling på Slien, sikrede man sig også indtægterne fra Sli-fiskeriet. I kraft heraf fastholdt vodfiskerne deres økonomiske uafhængighed og den sociale afstand til netfiskerne, og da den endnu eksisterede i 1820erne og 30erne, fæstnede vodfiskerne deres rolle som bestemmende gruppe på Holmen. Det garanterede også, at vodfiskerne fortsat stod som bærere af Holmens folkekultur og således, at skik og brug blandt Holmens fiskere også levede videre i næste generation.

I årene fra 1850 og til 1910 steg antallet af fiskere på Holmen i takt med befolkningstilvæksten: fra ca. 60 i 1850 til ca. 100 i 1900 . Desuden modsvaredes det stadigt større antal fiskere på fiskerlejet Holmen ikke af større sildefangster, der udgjorde fiskernes hovedindtægt. Samtidig satte afmonopoliseringen og privatiseringen af Sli-fiskeriet ind i 1845. Det betød, at fiskerlavets indtægter ikke længere var sikret så godt som i 1830erne. Dette var frem til århundredskiftet årsagen til stærke spændinger mellem vod- og netfiskere på Holmen. Striden om sildefiskeriet på Slien, der optrappedes i årtierne efter 1840 , bedrede heller ikke den økonomiske situation for Holmens fiskere, men uddybede blot den eksisterende konflikt.

Med svækkelsen af fiskerlavets stilling lokalt skete der en åbning af fiskersamfundet. Det betød en afvandring af især netfiskere, der søgte bort fra Holmen og ind til Slesvig, og dermed væk fra fiskeriet og over i andre jobs. Konsekvensen blev en omstrukturering af lokalsamfundet Holmen. I slutningen af 1800-tallet var det således ikke længere kun fiskere, der boede og arbejdede på Holmen, men også skomagere, snedkere, bagere, købmænd, fiskehandlere, røgere og kogekoner. Der- 


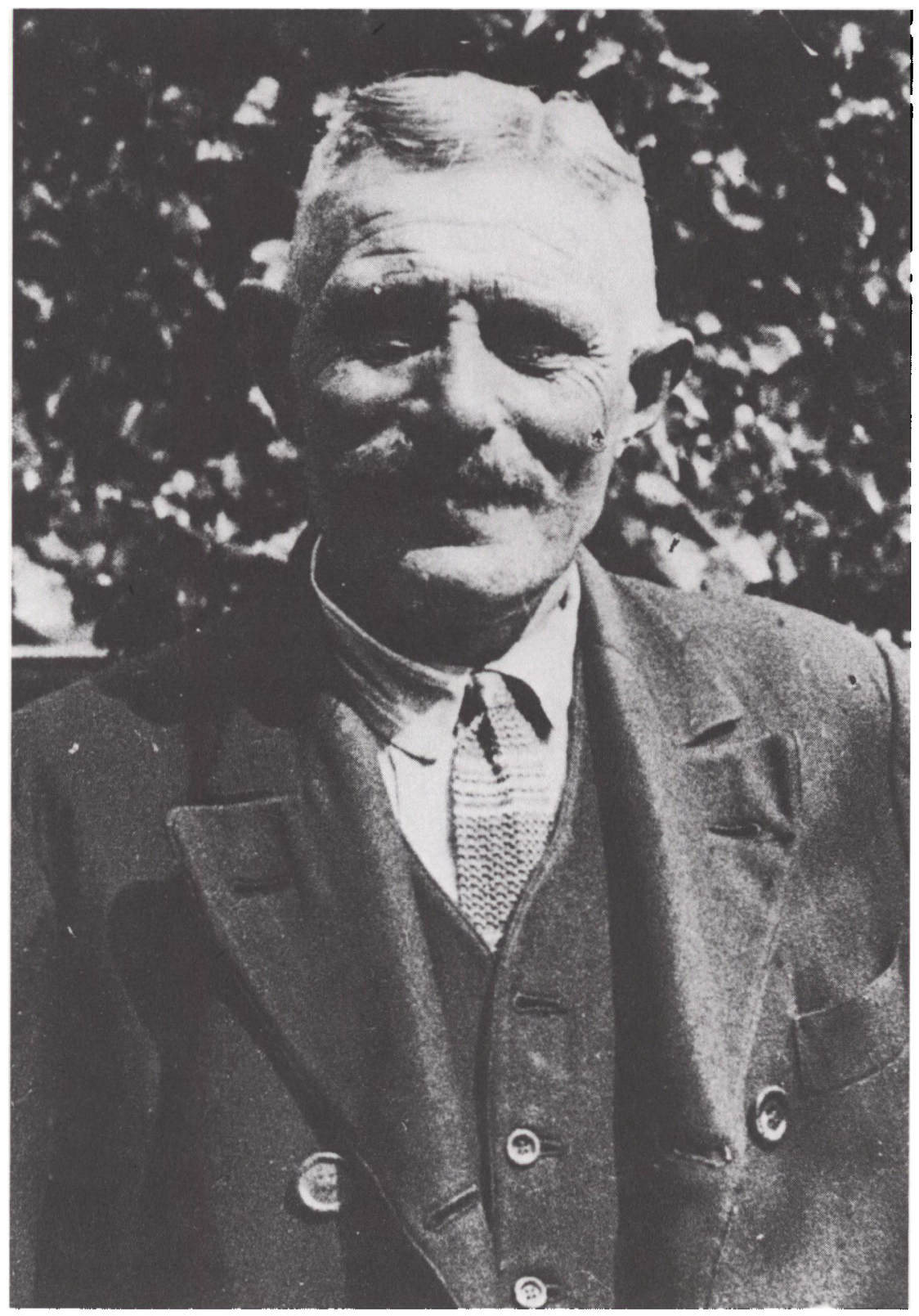

Nicolaus Nielsky (Niele), 1872-1933. Han havde samme ogenavn som sin broder August, og Niele er en afledning af Nielsky. Nicolaus kaldtes Nicke Niele og August Aue Niele. For at markere, at de var sde Kanink", Friedrich Nielskys sonner, omtaltes de til tider som »de Kaninken", kaninerne. 


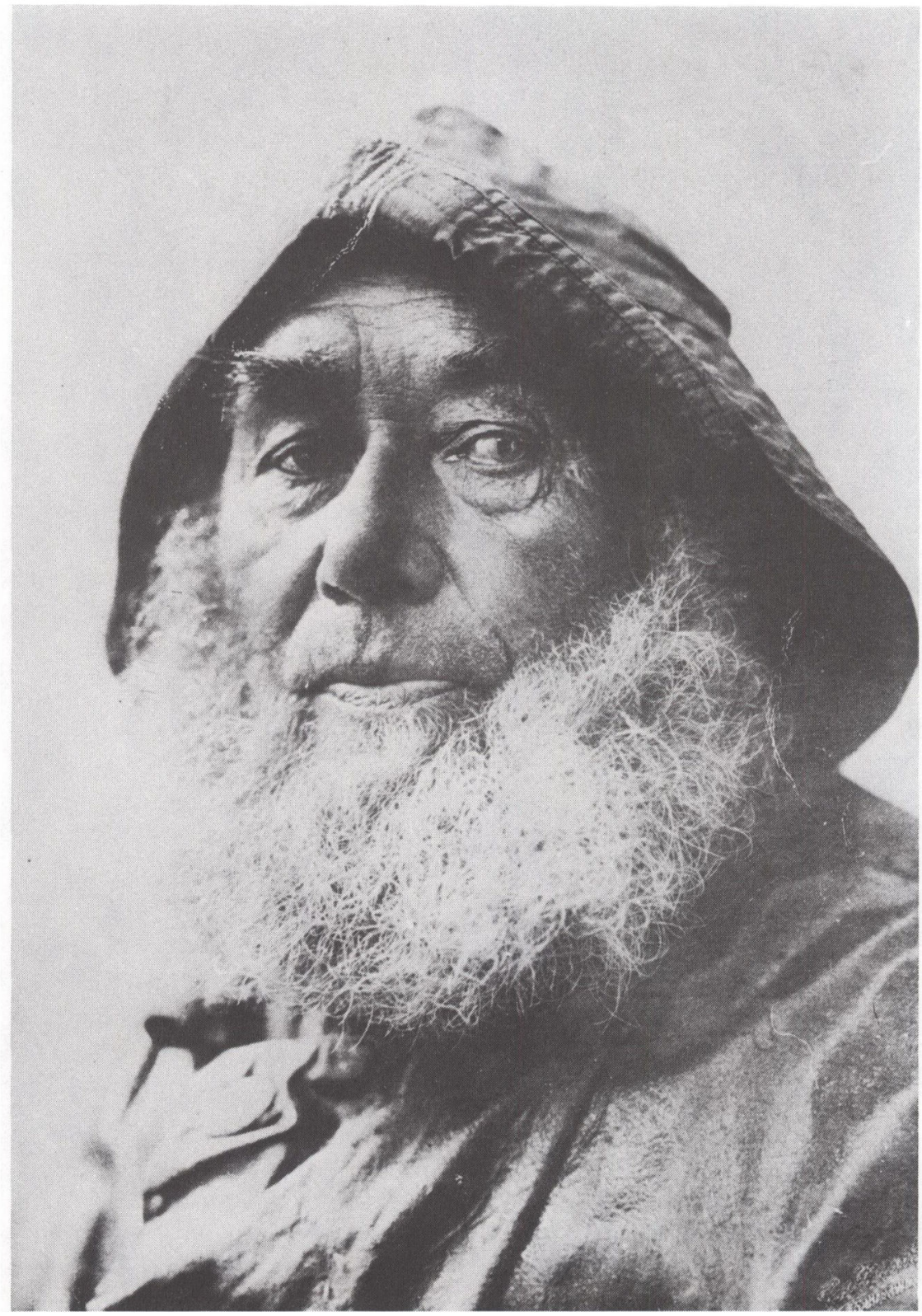

Friedrich Nielsky (de Kanink=kaninen), 1839-1920. 


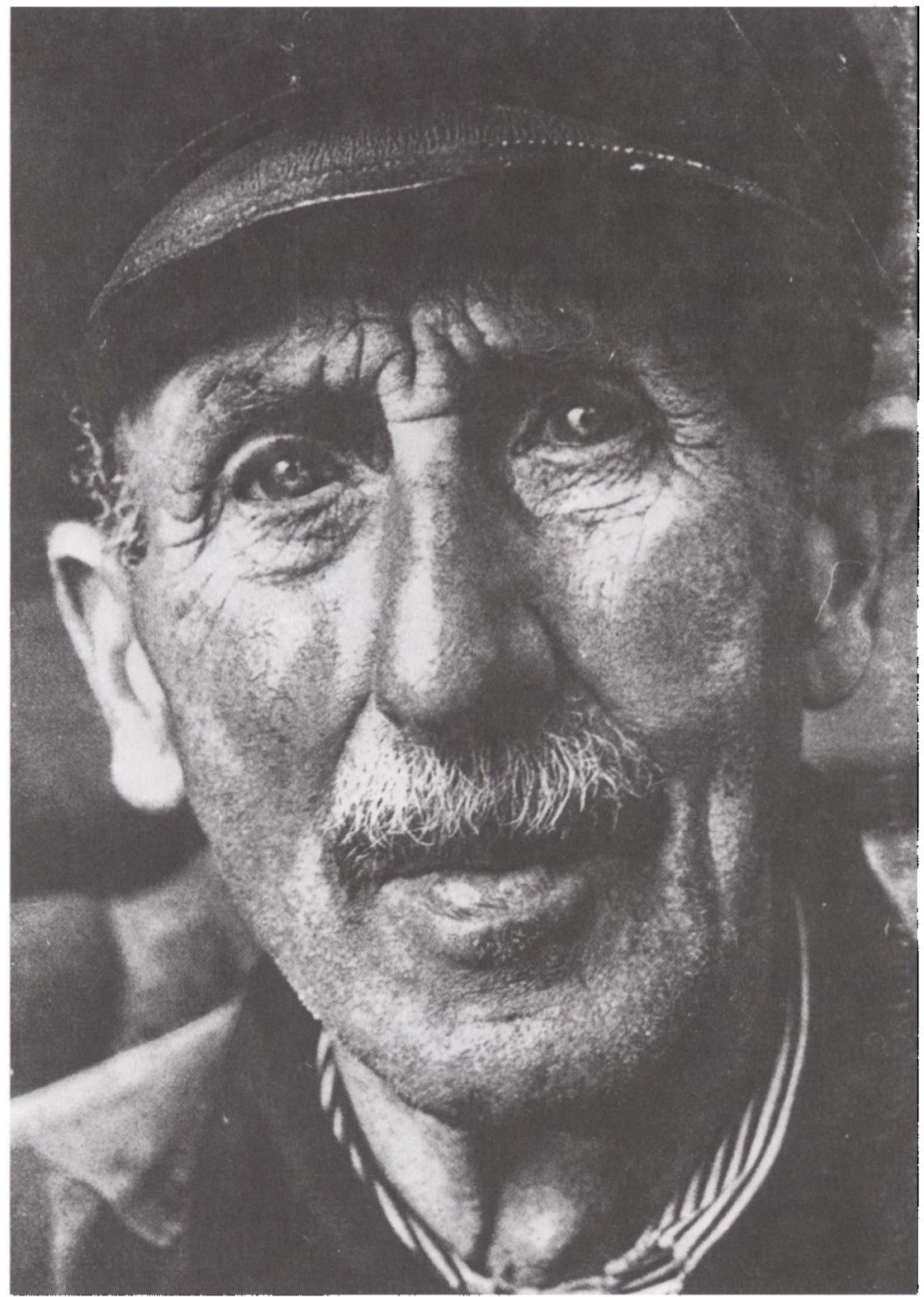

Johann Witt, 1867-1957, var en af de fá fiskere, der intet ogenavn havde. Der var sa fa fiskere $i$ Witt-familien, at ingen af dem havde ogenavne. 
med gik vodfiskernes rolle som bestemmende gruppe og bærere af fiskerlejets folkekultur tabt. Med åbningen af fiskerlavet omkring 1910 kunne også netfiskere deltage i vodfiskeriet. Dette slog fællesskabet mellem vodfiskerne, som vodfællesskaberne havde været udtryk for, $i$ stykker, og efterhånden som fællesskabet i og mellem vodfællesskaberne langsomt opløstes, gik også fiskernes almuekultur tabt.

En del af denne almuekultur var øgenavnene, der som omtalt udsprang af og brugtes mest i vodfællesskabet, men da det sidste vodfællesskab på Holmen opløstes i 1950, døde også øgenavneskikken hen. I dag bruges øgenavnene ikke mere på Holmen, men huskẹ dog af gamle fiskere og fiskerenker. Det er dem, jeg har interviewet.

\section{Hvad siger Holm-fiskernes øgenavne om fiskersamfundet?}

For at kunne skelne fiskerne fra hinanden, var øgenavne en simpel nødvendighed på Holmen, da især efternavnene på de større og store fiskerfamilier gik igen. Det var følgende familier: Reincke (62), Nanz (53), Möller (30), Roß (18), Fischer (18), Jensen (14) og Petersen (13). I parentes er nævnt antallet af registrerede fiskere fra de forskellige fiskerfamilier. Det var nemlig kun fiskere, der fik øgenavne.

Det viste sig, at man i ganske få tilfælde brugte et andet og mindre flatterende øgenavn, når man talte om, end når man talte med fiskeren. Brugte man det forkerte øgenavn i fiskerens nærværelse, blev han sur. Det var:

Detlef Jensen (Leier), der også omtaltes som Baron.

Johan Nanz (Diransch), som også gik under navnet de Blothund og de Aap.

Johann Fischer (Dalli), som også kaldtes Mochum og Horwitz. Jacob Möller (de Änt), der også benævntes de Woort.

Alle interviewede fiskere og fiskerenker kendte hinanden godt. Deres kendskab til familieforholdene på Holmen var så intakt, at fiskerfamilierne har kunnet rekonstrueres tilbage til ca. 1850 , enkelte endda til ca. 1815. Dette indgående kendskab til og tilbøjelighed til at iagttage den enkelte mærkes tydeligt i øgenavnestoffet, idet 167 ud af 314 registrerede øgenavne kan henføres til fiskernes udseende og fremtoning (59), hans vaner og uvaner (60) samt til afledninger, reduceringer og talefej1 (48). Her blot nogle få af dem:

Willy Jensen (de Aap) kaldtes også Terrier, fordi han havde et spidst mundparti. Det fik ham til at ligne en abe, andre syntes, en terrier. Andre igen opfattede ham som flabet (plat: aapig). 


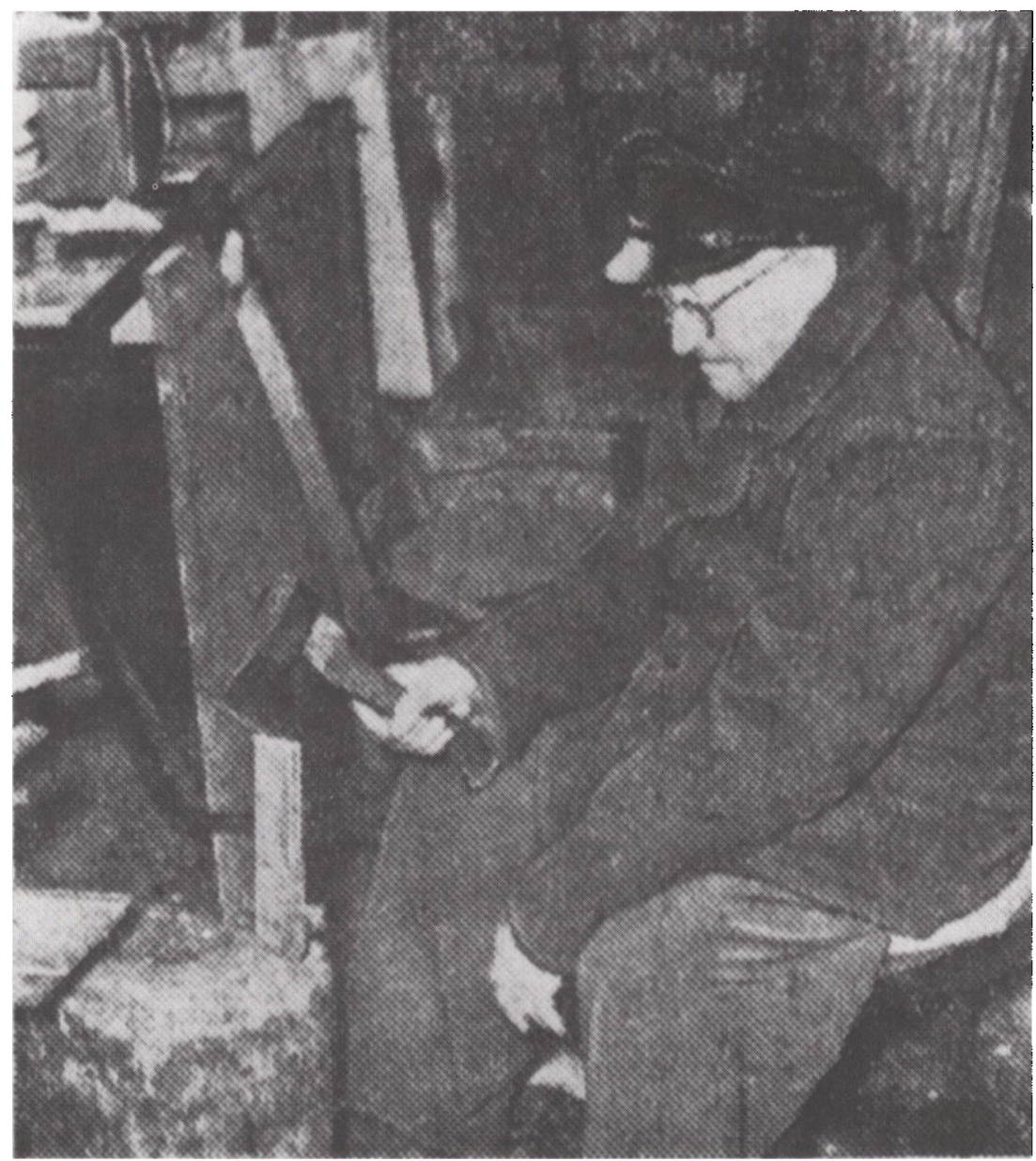

Detlef Jensen (Abs), 1855-1957. Foto fra 1951. Selv under vinterfiskeriet smogede han armerne op, så han derved kom til at ligne bokseren Abs. Denne har dog ikke kunnet identificeres. Som 96-drig hugger han her brande inde $i$ brandeskuret.

Bernd Kröger (Bambus) var fed og lignede på ingen måde et bambusrør.

Heinrich Vollertsen (Gandhi) var allerede som barn meget tynd. Da han tilmed som ung skulle bære runde sygekassebriller, mindede han på en prik om Mahatma Gandhi (1869-1948), hinduernes politiske og religiøse leder i Indien.

Detlef Jensen (Abs) smøgede selv under vinterfiskeriet ærmerne op, så 


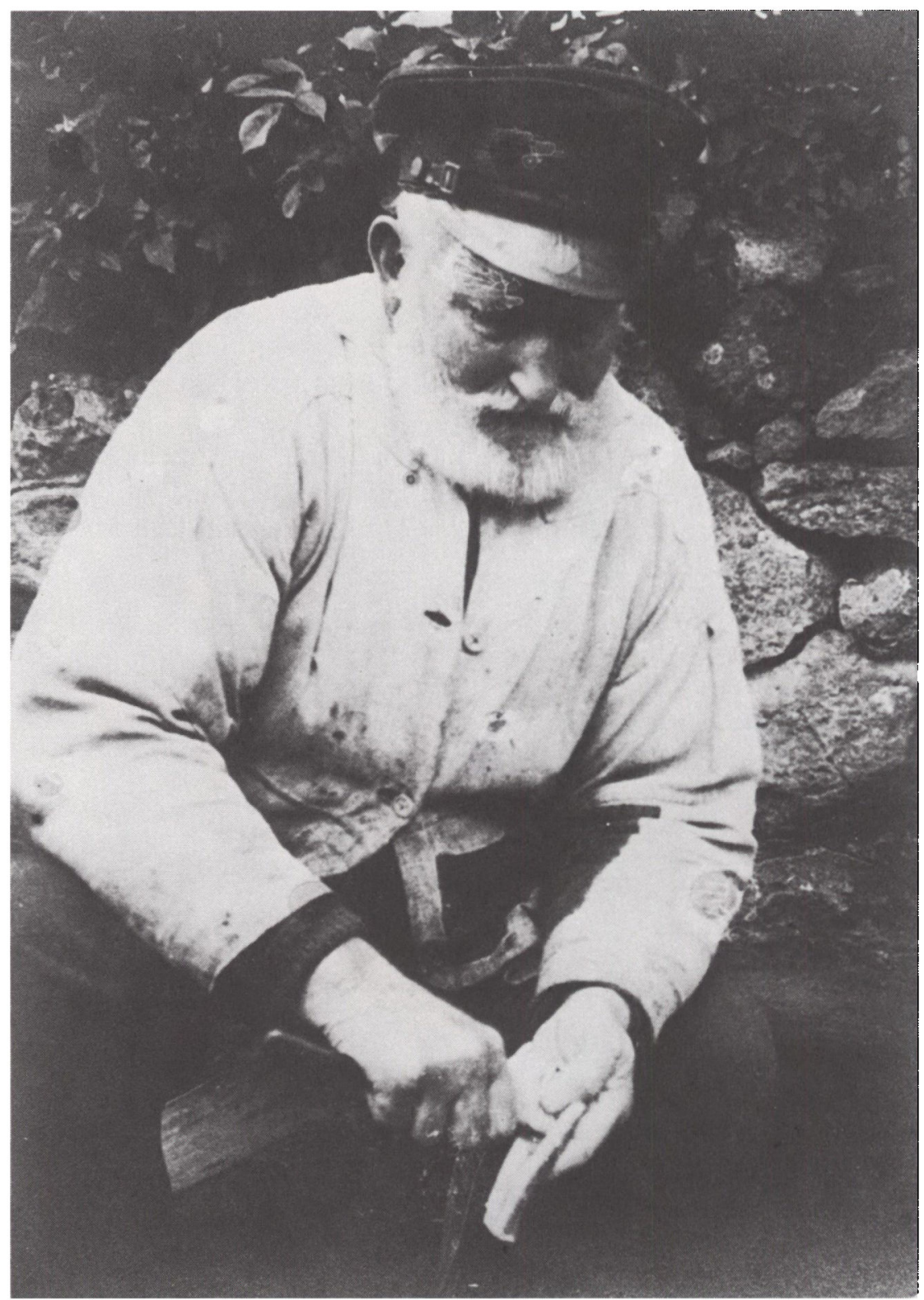

Friedrich Ross (Dodel), fodt o. 1850/55, ved at gore al rene. Ca. 1920/30. Grunden til ogenavnet har ikke kunnet findes. Det skal bemarkes, at Friedrich Ross (Meister), der ses på billedet s. 138, ikke er identisk med denne Friedrich Ross. Det viser, hvor nyttige ogenavnene var. 
han kom til at ligne bokseren Abs. Ingen af de interviewede har dog kunnet identificere denne Abs nærmere. Der har heller ikke eksisteret nogen bokseklub i Slesvig, så nogen lokal størrelse kan det heller ikke have været.

Johann Nanz (Dickkopp) var meget stædig, egensindig og tykhovedet (plat.: dickköppig).

Detlef Möller (Mohrich) var så sparsommelig, at det grænsede til nærighed (plat.: mohrig).

August RoB (Ausch) udtalte som barn sit fornavn som Ausch.

August Reincke (Iwi) er Klaus Reincke (Iwan)s søn. For at gøre dette helt klart, afledtes Iwi af Iwan. KR kaldtes Iwan, fordi han med sit røde hår lignede en russer.

Man har således været meget tæt inde på livet af hinanden, især dog under fiskeriet på Slien og mens man lappede net.

I øgenavnematerialet er registreret 249 fiskere med i alt 314 øgenavne, fordelt således:

Gravsten for Julius Hannberg (Null), 1879-1941, med indmejslet ogenavn. Han var den eneste ikke-fisker med ogenavn. Som mågekonge var det hans opgave, bistdet af drenge fra Holmen, at indsamle mågeaggene fra Mågeøen i Slesvig. Foto ca. 1978. 
194 fiskere med et øgenavn, heraf: 25

- 137 fiskere med et eget øgenavn 23

- og 56 fiskere kun med et nedarvet øgenavn

2

117

52

82

32

45 fiskere med to øgenavne, heraf:

34

20

- 24 fiskere med to egne øgenavne

23

22

- og 21 fiskere med et eget øgenavn foruden det nedarvede

10 fiskere med tre øgenavne, heraf: 1

- 4 fiskere med tre egne øgenavne 1

- og 6 fiskere med to egne øgenavne foruden det nedarvede
$-$

$-$

17

6

6

3

3

\section{7}

15

3

$-$

3

Fordelt over perioder har der altså kunnet registreres 26 fiskere med 28 øgenavne for tiden $1800-49,146$ med 181 for $1850-99$ og 77 med 105 for 1900-49.

Gravsten for Carl Reincke (Ammi), 1870-1956, med indmejslet ogenavn. Ingen af fiskerne eller fiskeenkerne på Holmen har kunnet forklare ogenavnet. Foto ca. 1978.

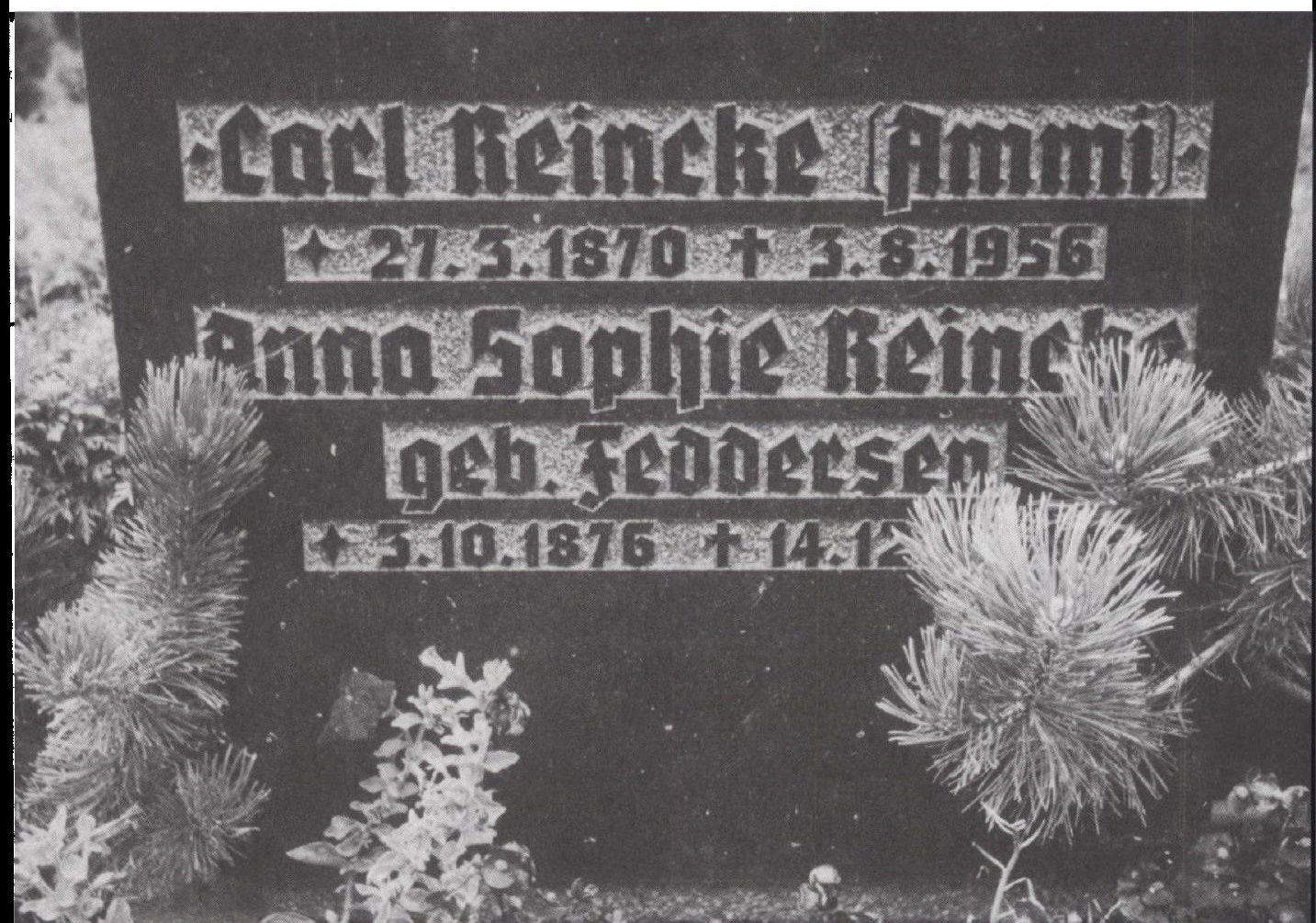




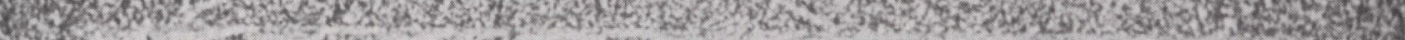

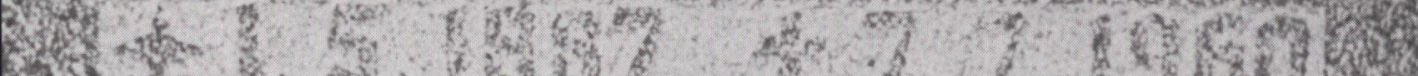

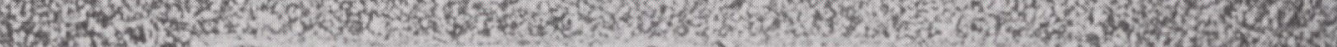
4.

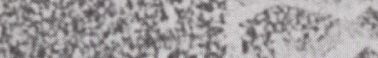

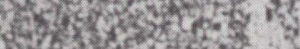

I.

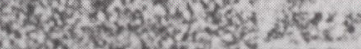
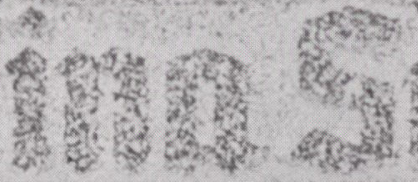

बist

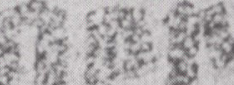
सेt?

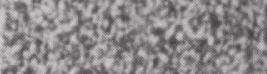

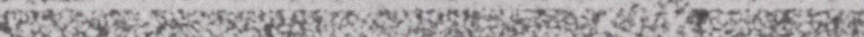

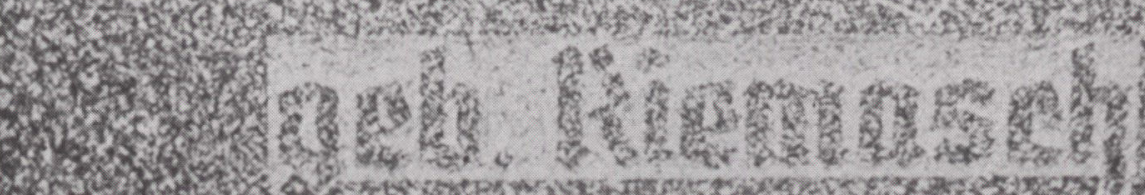

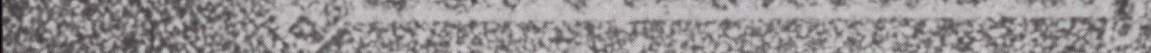

Gravsten for Johann Sager (Eika), 1887-1960, med indmejslet ogenavn. Forklaring pd øgenavnet kan ikke gives. Foto ca. 1978.

Gravsten for Fritz Reincke (Grote), 1891-1961, med indmejslet ogenavn. Han var den aldste af bornene derhjemme, eller som man siger i daglig tale: den storste. I hvert fald omtalte moderen ham konstant kun som "min Groter. Foto ca. 1978.

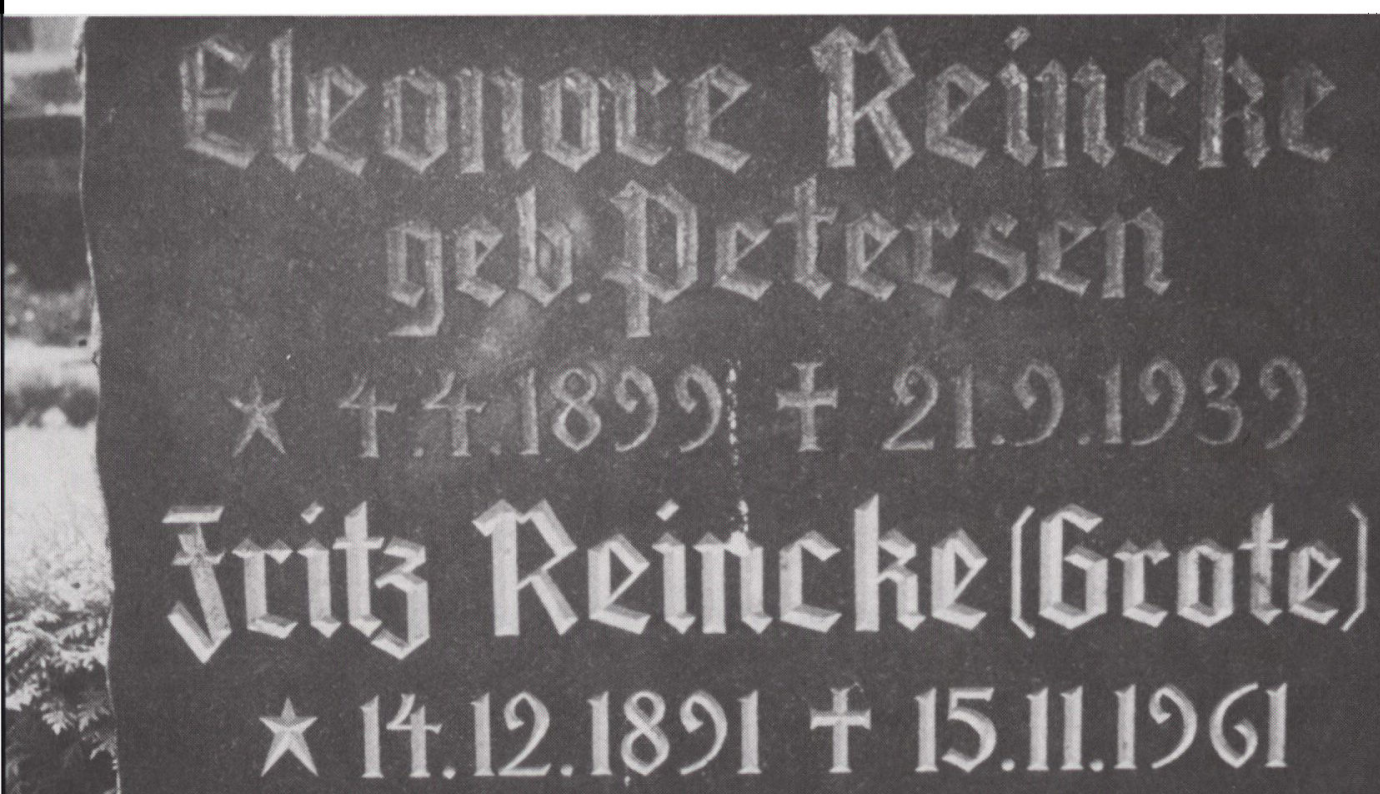


Statistikken belyser to forhold. Det ene: at antallet af øgenavne følger antallet af fiskere fra ca. 40 i 1800 til ca. 100 i 1900, 108 i 1923 og 84 i 1932 (heraf kun $30 \mathrm{i}$ arbejde). Fiskernes antal holder sig således konstant i årene 1900-30, men efter den tid tyder meget på, at fiskerlavet næsten ingen tilgang har haft af unge fiskere, og færre fiskere betyder færre øgenavne. Dertil kom, at fiskersamfundet åbnede sig stadigt efter 1900 , og at det $\mathrm{i}$ takt hermed blev stadigt mindre almindeligt at bruge øgenavne.

Man må dog heller ikke overse, at der i 1800-49 nok har fandtes en del flere øgenavne, end tallet umiddelbart tyder på. Dette alene af den grund, at antallet af fiskere i 1800-50 har ligget på 40-50, mens der kun er registreret 26. Endvidere husker de gamle fiskere og fiskerenker, jeg har talt med, også bedst den tid, de selv og deres forældre har levet med i. Jeg er således under indsamlingsarbejdet stødt på øgenavne, som de interviewede godt nok mente at have hørt engang, men ellers ikke kunne huske noget om.

Det andet, statistikken tydeligt viser, er fiskersamfundets åbning efter 1850 . Dette ses af, at der alene i $1850-99$ er registreret 43 og i 19004938 nedarvede øgenavne. Øgenavnene mister derved deres betydning som betegnelse for et personligt særpræg og går i stedet over til at markere, hvilken gren af familien, man tilhører.

Kendetegnende her er, at det især er de store og større fiskerfamilier på Holmen, hvor de nedarvede øgenavne holder sig igennem generationer. Det er: Jensen (Leier), Möller (Leus), Nanz (Nacke), Reincke (Buer), Reincke (Jöns), Reincke (Kack), Reincke (Pati) og Roß (Meister). I Möller-Leus' og Reincke-Patis tilfælde er øgenavnet endda blevet til en fast bestanddel af efternavnet.

De nedarvede øgenavne udgør godt $30 \%$ af øgenavne-stoffet efter 1850. I tal: 81 af 286 registrerede øgenavne. Man kan derfor med god ret tale om en tiltagende anonymisering af øgenavnene. Desuden har ca. $25 \%$ af de registrerede fiskere efter 1850 to eller flere øgenavne. I tal: 54 af 223 fiskere. Altsammen en konsekvens af fiskersamfundets åbning.

$\mathrm{Da}$ det kun var fiskere og fiskersønner, der fik øgenavne, viser det stærke fald $i$ antallet af registrerede fiskere og øgenavne for tiden 1900 49, at åbningen af fiskersamfundet nu helt og holdent er slået igennem. I tal: fra 146 fiskere og 181 øgenavne i 1850-99 til 77 fiskere og 105 øgenavne i 1900-49. Færre nye øgenavne betyder således også en nedadgående tendens for tilgangen af nye fiskere.

Som omtalt betød åbningen en afvandring af fiskere fra fiskerlejet Holmen og ind til Slesvig, bort fra fiskeriet og over i andre erhverv, og 
dette fremskyndede så igen omstruktureringen af fiskersamfundet. Denne omstrukturering spores endda i øgenavnestoffet, omend kun svagt. Kun 12 af 181 øgenavne fra tiden $1850-99$ går tilbage til et erhvervsskift, såsom:

Christian Fischer (Bretter), der blev tømrer (ty.: Bretter = da. bræt). Klaus Reincke (Buer), der havde en vis tilknytning til landbruget. Han hjalp en del til på svigerfaderens lille landbrug ud mod Slien: med at passe hønsene, kaninerne, ænderne og fårene (plat.: Buer $=$ da.: bonde).

Jonny Reincke (de Flottenschoster) var oprindeligt udlært skomager (plat.: Schoster), men meldte sig senere som frivillig til marinen (ty.: Flotte).

Wilhelm Mahnke (Himmelblau), der var gartner på fiskerlejet Holmen, gik rundt med sin trækvogn og solgte »himmelblaue Bickbärn« (da.: himmelblå blåbær). Han var dog ikke af fiskerfamilie.

Johann Möller (Schnieder) var skrædder (plat.: Schnieder).

Jürgen Nanz (Setzer) var typograf (ty.: Schriftsetzer).

Da langt størstedelen af disse øgenavne kan dateres til 1880-1900 understreger det, at strukturændringen er sket i de år.

Gravsten for Christel Nanz (Nacke), 1885-1966, med indmejslet ogenavn. Han var tredje generation af Nanz-familien, der bar dette ogenavn.

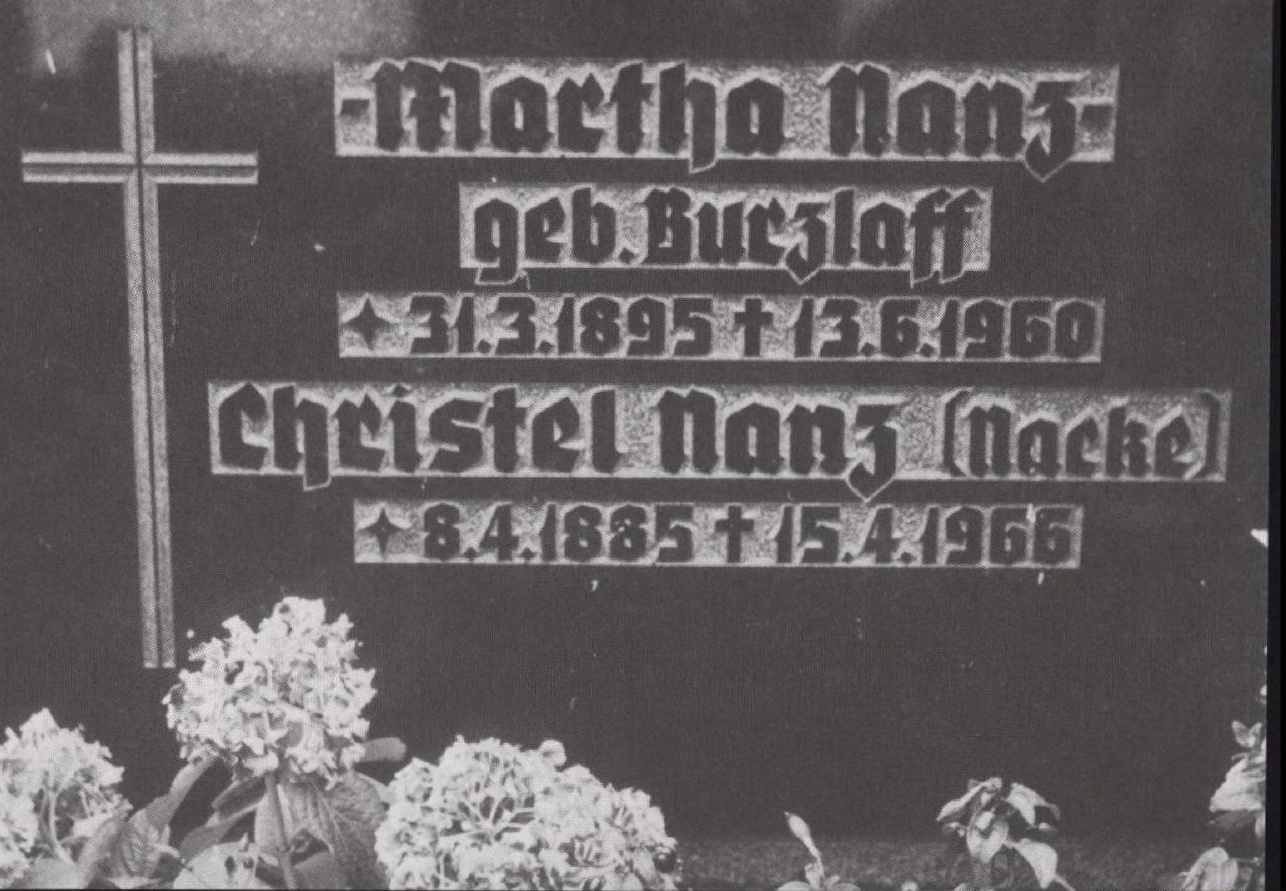




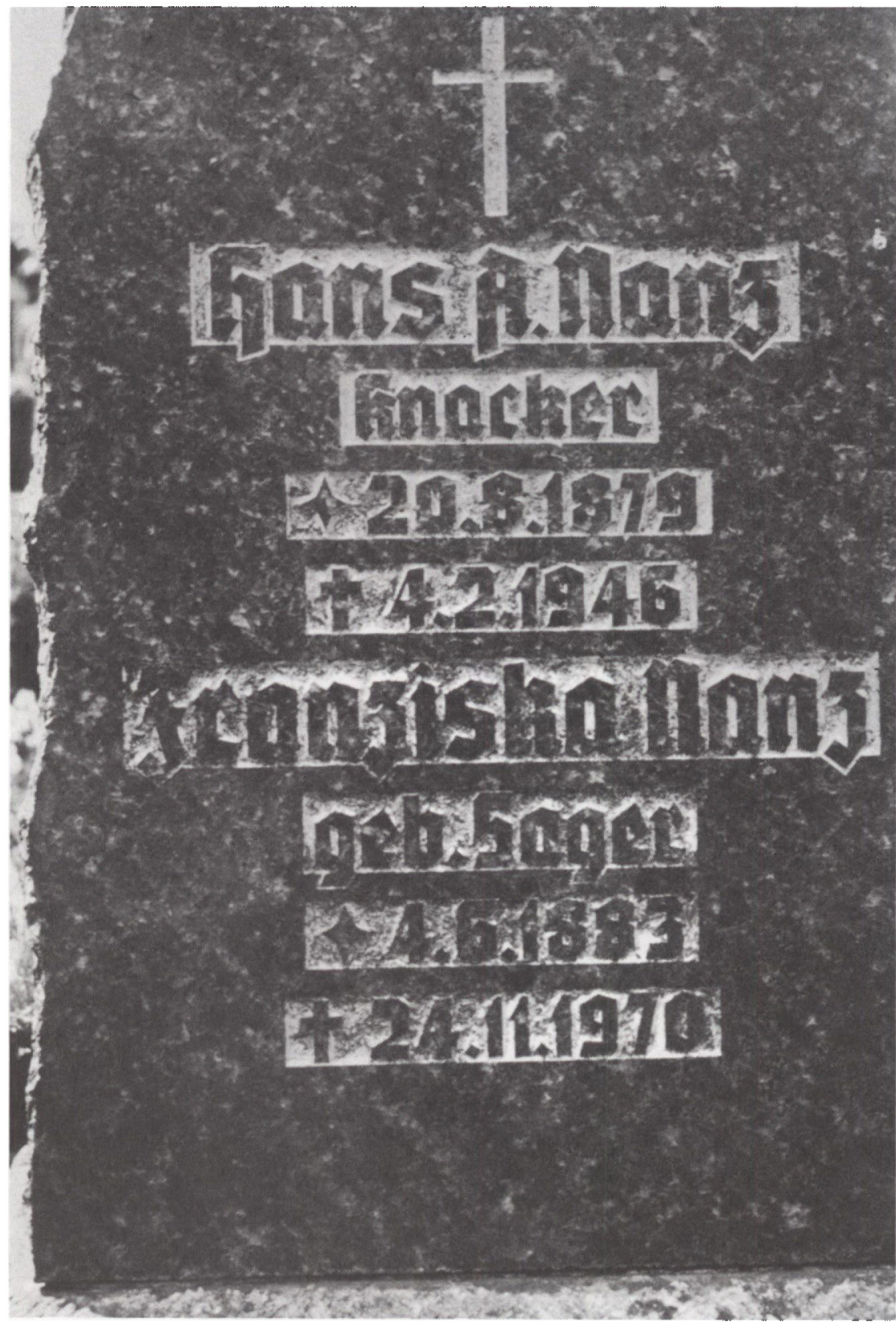

Gravsten for Hans A. Nanz (Knacker), 1879-1946, med indmejslet ogenavn. Han kladte sig engang som barn ud til fastelavn som neger, der pa tysk noget nedsattende kan kaldes »Knacker«. I omgangssproget blandt fiskerne blev det til »Knacker\%. Foto ca. 1978. 
Som nævnt fandtes der på Holmen en vis afstand mellem vod- og netfiskere, hvad enkelte øgenavne også giver en svag anelse om. Her er et par af dem:

Detlef Jensen (Baron). Som syerske færdedes hans mor hjemmevant $i$ Slesvigs købmandskredse, og fik ad den vej godt brugt tøj foræret, der var som skræddersyet til sønnen Detlef. Han var derfor altid korrekt og fint klædt på, som en baron, mente fiskerne på Holmen. Desuden syntes nogle, at han stak næsen lidt for meget i vejret og teede sig som en baron. I Angel, som Holmens fiskere havde nære kontakter til, kalder man en, der gør sig til mere end han er, for en Baron von Havenick (ty.: Baron von Habenichts).

Detlef Möller, Adolf Möller og Johan Nanz (de dree Ministers) deltog sammen i den tysk-franske krig 1871 . Dette placerede dem socialt en tak højere end de andre fiskere på Holmen. Hvem af dem, der kaldtes

Gravsted for Friedrich Reincke (Pati), 1904-1976, med indmejslet ogenavn. Der er flere forklaringer på ogenavnet. Den ene er, at han $i$ udstillingsvinduet til en tojforretning $i$ Slesvig så nogle seler. Skiltet med teksten »eine Partie Hosenträger blev $i$ hans udtale til weine Pati... En anden forklaring gär ud pd, at han var et yderst sympatisk menneske; deraf afledningen Pati. Ogenavnet er sidenhen blev nedarvet i fire generationer af Reinckefamilien. Foto ca. 1978. 


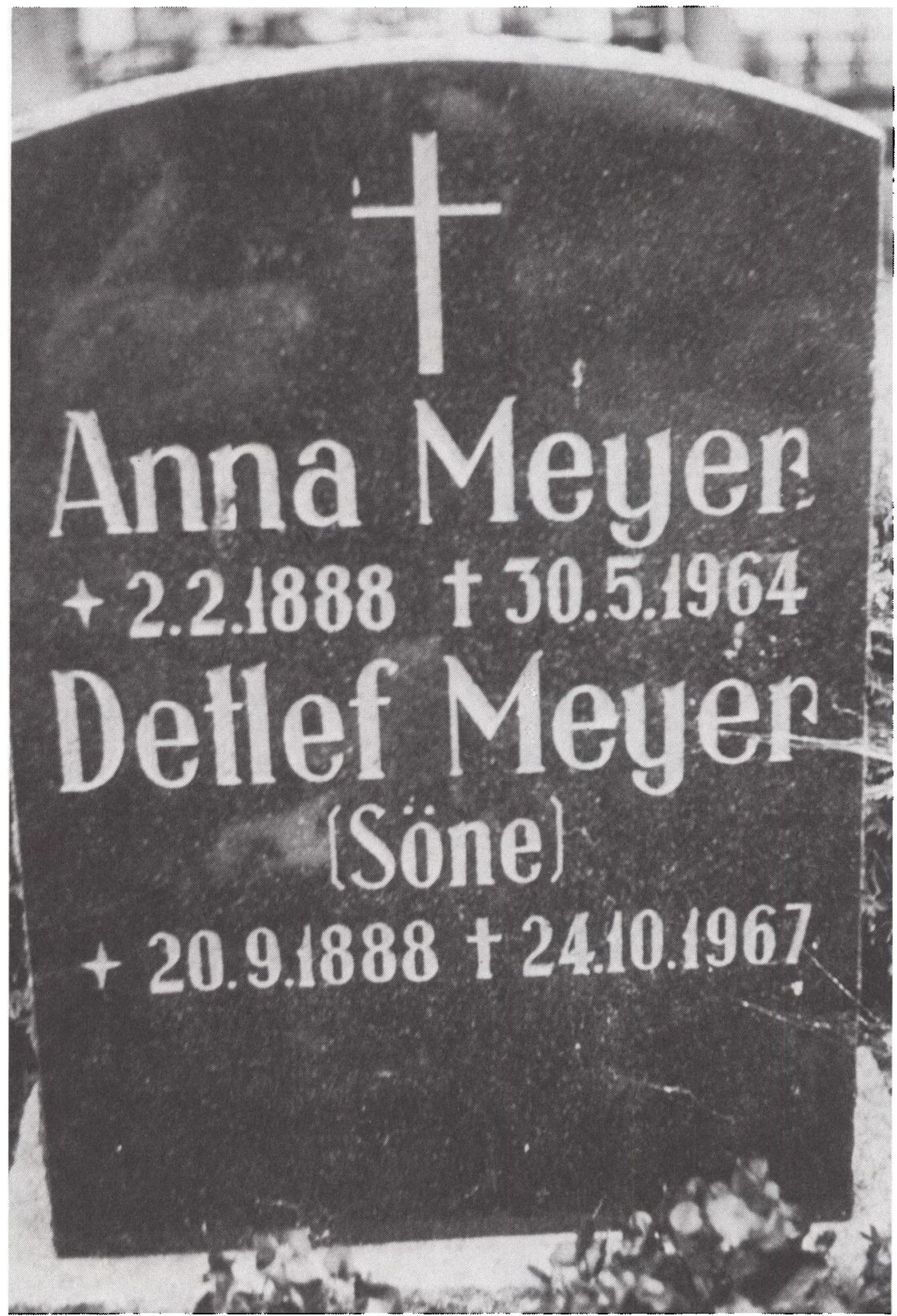

Gravsten for Detlev Meyer (Söne), 1888-1967, med indmejslet ogenavn. Det fortalles, at han, når han og sonnerne skulle ud at fiske, havde for vane at genne på dem: »Söne, Söne, komm!«. Foto ca. 1978. 
Bismarck, Rohn og Moltke, kunne ingen af de interviewede dog oplyse.

Johann Reincke (Puttkammer) var ikke kun meget fornem i sin'optræden, men mindede tilmed på en prik om kammerherre v. Puttkammer i Slesvig.

Theodor Reincke (Scherf) bar til begravelsesgildefestlighederne på Holmen og til andre fine lejligheder altid et skærf (plat.: Scherf) om livet, og det endda i de slesvig-holstenske farver blåt-hvidt-rødt.

Christian Fischer (Schipperduk) var vodleder (plat.: Schipper) for et af Holm-fiskernes vodfællesskaber. Når vodfiskerne i svag vind fiskede ude på Slien, advarede voddets fiskere ham mod at få sejlet i hovedet: "Schipper, duk di!« (da.: skipper, duk dig). Deraf afledtes Schipperduk. Holm-fiskerne havde også deres outsidere, der vel især hørte til gruppen af socialt dårligst stillede på fiskerlejet Holmen. Disse outsidere var hverken accepteret af eller integreret i fiskersamfundet, og det på trods af, at de som fiskere boede på Holmen. Ársagerne hertil kunne være mange. Om det nu var ens væsen eller livsform, der adskilte sig alt for stærkt fra de andre fiskeres eller fiskerfamiliers, om man i fiskernes øjne var dum eller måske rablende skør; man stod ihvertfald uden for fiskersamfundet.

I arkiverne finder man intet om alt dette, men den folkelige overlevering igennem øgenavnene giver et tydeligt indtryk af, at sådan må det have været. Læs selv:

Friedrich August Möller (Möh) virkede træt (plat.: möh) og dum. Desuden var han langsom i optrækket.

(?) Möller (Jeck) var rablende skør (plat.: jecksch).

Daniel Möller (Doktor) var meget belæst og således en sjælden undtagelse blandt de ellers ikke-læsende Holm-fiskere.

Johann Lorenz Fischer (de Kaffedrinker) gjorde grin med dem, der ikke drak snaps og kaldte dem kaffedrikkere (plat.: Kaffedrinkers). Selv var han dog alkoholiker, netop på grund af sin hang til kaffepunch: altså til kaffe, tilsat brændevin.

Christian Reincke (Ritter) var gal, idet han påstod, at han ejede herregårde og var gift med baron v. Brockdorff på landstedet Annettenhöh nær Slesvig. Derfor var han ofte henne ved baronens gravsted i landstedets park. Dertil kom, at han påstod, hans kæreste var Marie zu Holstein-Sonderburg-Glücksburg, og at han havde forhandlet med v. Hindenburg. Disse påståede fornemme bekendtskaber gjorde, at han af fiskerne på Holmen kaldtes Ritter.

Georg Hannberg (de schwadde Georg). Hans sorte teint og hele livs- 
lokalsamfund, hvor familierne boede tæt op ad hinanden. Alle kendte alle, og især $i$ arbejdssituationer, som udfyldte en stor del af Holmfiskernes dagligdag, var man tæt på hinanden. Manden var fisker, og han forsørgede familien. Hans domæne var Slien, hvor han fiskede, nettørrepladsen Friheden, hvor han lappede sine net og redskabsskuret, hvor han opbevarede sine fiskeredskaber. Kvinden derimod stod for husholdningen og børnenes opdragelse, men hjalp tildels også med at lappe net, og sønnen hjalp sin far, datteren sin mor.

Selv om alle kendte alle, fandtes der dog alligevel en vis social afstand mellem fiskergrupperne på Holmen, og lokalsamfundet havde tydeligt nok sine outsidere, der ikke var accepteret af fællesskabet. Holmens fiskere var altså ikke nogen ensartet gruppe; der var snarere tale om to. Den ene: vodfiskerne, der fiskede med drivgarn (vod), og som var organiseret i fiskerlavet, hvor de nød godt af det fælles sociale sikkerhedsnet. Og den anden: netfiskerne, der fiskede med sættegarn (net) og snører. Disse fiskere var ikke kun uorganiserede, men også materielt og socialt betydeligt dårligere stillet end vodfiskerne.

Også åbningen og den deraf følgende omstrukturering afspejler sig i øgenavnestoffet, idet en række øgenavne fra årene 1850-99 går tilbage til et erhvervsskift. Disse øgenavnes tyngdepunkt ligger i perioden 1880-1900, hvilket tyder på, at strukturændringen slog igennem i de år.

I det store og hele bekræfter og supplerer øgenavnestoffet kildernes udsagn om fiskersamfundet. Kilderne giver os således et godt indtryk af den sociale afstand mellem fiskergrupperne, af den økonomiske udvikling på Holmen, af fiskeriets organisation og af fiskerlavets stærke stilling i lokalsamfundet. Øgenavnestoffet derimod går i langt højere grad ind på den enkelte fisker, og er meget afslørende med hensyn til fiskernes karakteregenskaber. Kun i få tilfælde siger de dog noget om den enkelte fiskers placering i fiskersamfundet, og omkring fiskerlejets åbning ud mod flertalssamfundet. Øgenavnene bliver derved sammen med kilderne et vigtigt middel til at afsløre en del af virkeligheden om dette særegne lokalsamfund. 